\title{
EMPLOYER BRANDING AND EMPLOYEES' COMMITMENT IN INTERNATIONAL ENTERPRISES
}

\author{
Anna KACPRZAK ${ }^{1}$, Marzena KACPRZAK ${ }^{2}$, Izabela WIELEWSKA ${ }^{3 *}$ \\ ${ }^{1}$ Warsaw Management University, Poland; kacprzakania@interia.eu, ORCID: 0000-0002-8224-3895 \\ ${ }^{2}$ Warsaw University of Life Sciences - SGGW, Poland; marzena_kacprzak@sggw.pl, \\ ORCID: 0000-0002-0680-8241 \\ ${ }^{3}$ UTP University of Science and Technology in Bydgoszcz; wielewska@utp.edu.pl, \\ ORCID: 0000-0002-1721-6890 \\ * Correspondence author
}

Purpose: Employer branding is one of the most important indicators of an organization's value. Employers use newer and newer tools to build and stimulate employee engagement. Their diversity should now be considered primarily in the context of culture and globalization processes including broadly understood internationalization. Many companies have focused on employee safety and stability. The focus was on trying to identify certain differences and similarities in this area.

Design/methodology/approach: Based on the collected statistical data, the authors' own observations and the subject literature on the research, an attempt was made to check the relationship between Employer Branding and employee commitment in international companies. For this purpose, a pilot study was carried out among 105 IT directors in Spain, France and Sweden. Purposive sampling was applied for the research sample.

Findings: The analysis of the results shows that there is a close relationship between the Employer Branding strategy and employee commitment in their work. The research results show both certain similarities and differences in the approach to the discussed issues from the perspective of different countries. Conscious building of the image of the organization as a perfect workplace for current employees and all groups of future stakeholders is the basic principle of every business activity. In order to become an employer of choice, an organization should follow clearly defined principles, trust its employees and satisfy their needs. The research has shown that a decrease in employee commitment in work does not always have a negative impact on the image of the employer, and the SOP strategy used has a positive effect on both the company's image and employee engagement. An alarming fact from the cited studies is the mutual lack of trust between owners and managers of individual enterprises and employees. Low employee commitment rates in individual countries may result from an incorrectly designed incentive system.

Practical implications: Knowledge and tools on building employee engagement in international IT companies can be used in other sectors of the economy, which will have a positive impact on the moulding of the relationship capital with stakeholders.

Social implications: As part of the SOP strategy, the following aspects are implemented: economic, social, environmental and ethical. The implementation of all these aspects positively 
shapes the company's relations with its stakeholders, which is presented in the company's social reports.

Originality/value: The results of the research enrich knowledge about the relationship between Employer Branding and employee involvement in international companies.

Keywords: employer branding, employee engagement, organizational culture.

Category of the paper: research paper.

\section{Introduction}

Employer branding (EB) means building an employer brand. It is a long-term strategy focused on attracting talented employees, and especially on building their commitment, and thus on bonding them with the employer for a longer period. Committed employees become "ambassadors" of their organization, both inside and outside it. EB and building employee commitment can be ranked among the strategic processes of improving contemporary organizations around the world.

The actions and attitudes of leaders, the policy and practices of employers play a significant role in EB. A number of people and departments, including HR, PR and marketing, must be involved in the creation and moulding of the EB strategy. Employers use newer and newer tools to build and stimulate employees' commitment. Their diversity should now be considered primarily in the cultural context, globalization processes, including broadly understood internationalization. EB can be considered a new HRM trend that many companies operating in the world are part of.

The aim of this article is to indicate and compare the tools used to build and stimulate employee commitment and EB strategies by employers from selected European countries and to attempt to identify the differences and similarities in this area. For this purpose, a research study was conducted among 110 IT directors from France, Spain and Sweden.

The paper formulates a thesis that there is a two-way relationship between Employer Branding and employee commitment. Despite cultural, economic and political differences, it is possible to find joint organizational activities that have a positive impact on employee engagement and the employer's brand of multinational companies.

\section{The concept of Employer Branding}

It is thought that the precursors of the EB concept are S. Barrow and T. Ambler, who used the definition of EB that they formulated for the first time in a 1996 article entitled The Employer Brand. According to them, it is "a set of functional, economic and psychological 
benefits offered through employment with a given employer, easily identifiable with a given employer's company" (Ambler, Barrow, 1996, p. 187). The economic benefits should be understood in the context of wages and salaries, the functional benefits in relation to the employee's development, and psychological benefits mainly in the context of a strong sense of identification with the organization.

In 1998, advisors from McKinsey consulting company joined the discussion on the essence and need of creating EB; they pointed to the fight for talents as a key determinant of building the employer's brand (Chambers et al., 1998, Axelrod et al., 2001).

Although the concept of employer branding has been in use for many years, there is still no definition compliance among authors. M. Kozłowski defines employer branding as "all activities undertaken by an organization, addressed at current and potential employees, aimed at building its image as an attractive employer and supporting its strategic business goals" (2012, p. 14). EB is perceived slightly differently by A. Mayo, who emphasizes that this concept should be understood as "everything that is communicated (consciously or not) to every current or future employee" (2001, p. 123). EB is also defined as "the sum of the efforts of an organization to communicate to current and future staff that the company is a desirable workplace" or as "attracting talented individuals to an organization and ensuring that both current and potential employees identify with the company (its brand and its mission) and deliver the results it desires" (Bednarska-Olejniczak, 2013, p. 17).

2004 was an important year from the point of view of shaping the EB concept. It was then that two scientific articles were published: one on employer branding (emphasizing the impact of external factors on building the employer's brand), and the other on employee branding (the influence of internal factors on building the employer's image) (Dąbrowska, 2014, p. 217).

Parallel to these concepts, a third concept appeared in the subject literature - a corporate brand model indicating the need for employers to build their brand. Again, there are two different stances on this issue: some scientists do not separate the employer's brand from the corporate brand, believing that brand assessment is affected by both external and internal factors (including M. J. Hatch and M. Schultz), while others take the opposite stance (Dąbrowska, 2014, p. 27).

\section{Employer Branding and employee involvement}

There are three key concepts of employee involvement (Juchnowicz, 2010, p. 34):

1. Commitment as a kind of employee's attitude.

2. Behavioural involvement, expressed in specific behaviour.

3. Commitment based on the mutual exchange of experience between the employee and the organization. 
According to M. Armstrong, committed employees are genuinely interested, absorbed in, and even passionate about their work, which prompts them to undertake voluntary efforts that go beyond formal duties. On the other hand, the Gallup Institute (the oldest institute of public opinion research in the world) defines commitment as "joining in and being enthusiastic about work" (2009, p. 123).

"Employees' commitment can manifest itself in various forms: as organizational commitment to the company in which they are employed, as commitment to their work, profession or to the social environment in which they function" (Król, Kacprzak, 2016, p. 182).

For contemporary organizations, employee commitment becomes a business necessity. It affects profits, customer satisfaction and, undoubtedly, influences the creation of their image. The growing interest in the area of employer branding and building employee engagement is evidenced by the increasing number of contests for companies, e.g. Great Place to Work ${ }^{\circledR}$ Contest (BRIEF, 2019), the Best Employers Program - building an engaging organization/Aon Best Employers (Aon Hewitt) (BRIEF, 2018), or the Leader of Human Resource Management (IPiSS, 2019), which are becoming more and more of a success.

The Aon Best Employers program can be classified as the largest and most objective research and diagnosis of organizations in terms of employee commitment in Poland. So far, over 570,000 employees from companies of various scales of activity and employment have been surveyed during the 13th edition of the competition. Value estimation criteria were used according to four key factors: employee commitment, engaging leadership, high performance culture and credible employer brand.

In 2018, organizations such as: Egis Polska, Hotel InterContinental Warsaw, Mary Kay Poland, NUTRICIA ELN Polska, OMD Group, Vivus Finance Sp. z o. o., ANG Spółdzielnia, Benefit Systems SA., Grupa Pracuj, Pramerica Życie (soon Unum Życie), Grupa Hotelowa Orbis and Marriott International have been honoured primarily for creating a culture conducive to effective engagement and motivation of employees, primarily by implementing actions focused on employee satisfaction (including employee participation, fair remuneration and systematic, joint work on the company's values. The research results emphasize the strategic importance of engaging leadership and values such as respect, wise management, innovativeness and ensuring a sense of self-fulfilment (Warzybok, 2020).

It should be noted that the report developed by Aon Hewitt shows that, globally, there was a decline in employee commitment for the first time since 2012. The Aon Hewitt's analysis of more than 5 million employees in over 1,000 organizations around the world showed that employee commitment fell from 65\% in 2015 to $63 \%$ in 2016 to $57 \%$ in 2017 and $52 \%$ in 2018 . The largest decreases were recorded in France, Sweden and Spain (AON, 2020).

According to the report, employees of companies from the IT industry are much more likely to speak positively about their organization than employees from other industries. When the employee's market clearly prevails over the employer's market, the building of the image of the company as a good and attractive employer becomes particularly important. The Corporate 
Social Responsibility strategy has a significant impact on the building of the employer's image. According to M. Żemigała (2007, p. 100), this strategy focuses on the issues of the external environment and aims at maintaining a balance between the interests of customers, employees and shareholders, as well as to provide certain services for the local community.

\section{Material and research method}

In order to check the relationship between Employer Branding and employee commitment in international companies, between July 12 and December 17, 2019, a pilot study was conducted among 105 IT directors. The research was done in Spain, France and Sweden. It used the diagnostic survey method including an interview technique and a research tool in the form of an interview questionnaire. The sampling was purposive as the research included enterprises employing 50-100 people, and the surveyed entrepreneur agreed to the study and had to be a director in an IT company and have at least 5 years of work experience in one corporation.

The research covered 105 directors, 35 from each of the three countries, i.e. Spain, France and Sweden. Each of the respondents represented a different company. An interview with each of the directors was conducted online using the Zoom application.

The obtained responses were grouped and statistically analyzed, using an Excel spreadsheet.

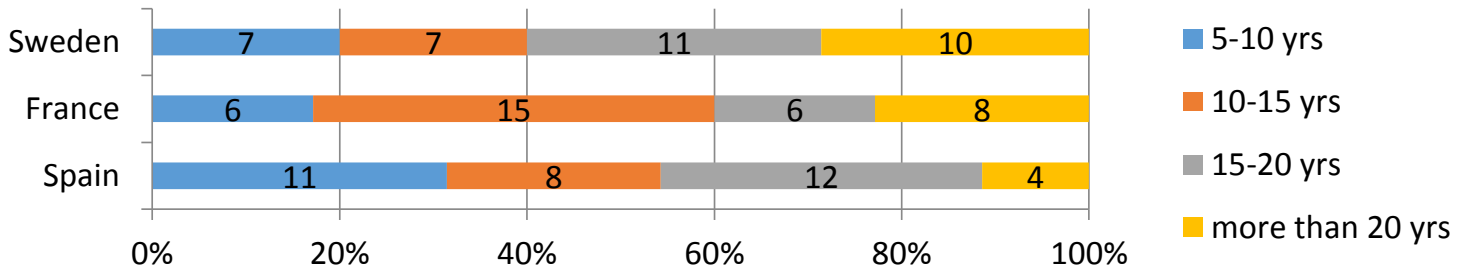

Figure 1. Work experience of the surveyed directors in IT companies. Source: author's own research.

Among the 105 surveyed IT company directors, the most (28.6\%) had 10-15 years of work experience, and the fewest had over 20 years (nearly $21 \%$ ). In Sweden, the largest number of directors $-31.4 \%$ - worked for $15-20$ years, and $28.6 \%$ worked for more than 20 years. In France, the largest number of respondents had 10-15 years of experience (42.9\%), whereas the largest number of directors in Spain had work experience of $15-20$ years $(34.3 \%)$ and 5-10 years (31.4\%). The work experience as a director in an IT company did not overlap with the overall work experience in a given company; as a rule, this period was shorter.

The IT company directors in all three surveyed countries were mostly male. In total, there were $77.1 \%$ of men. The remaining $23.9 \%$ of the respondents were women. An attempt was made to answer two research questions, namely: 
- Does the decline in employee commitment negatively affect the image of the employer?

- Do the tools used in the Corporate Social Responsibility strategy have a positive impact on the image of the company and the involvement of employees in doing their work?

A set of key questions included in the interview questionnaire allowed to answer the research questions posed.

\section{Research results}

In order to find out what the relationship between Employer Branding and employee commitment in multinational companies is, Swedish, Spanish and French IT directors were asked to answer seven main questions. The first question - How to recognize a committed employee? - had similar answers provided by the directors from Sweden, Spain or France (Figure 2).

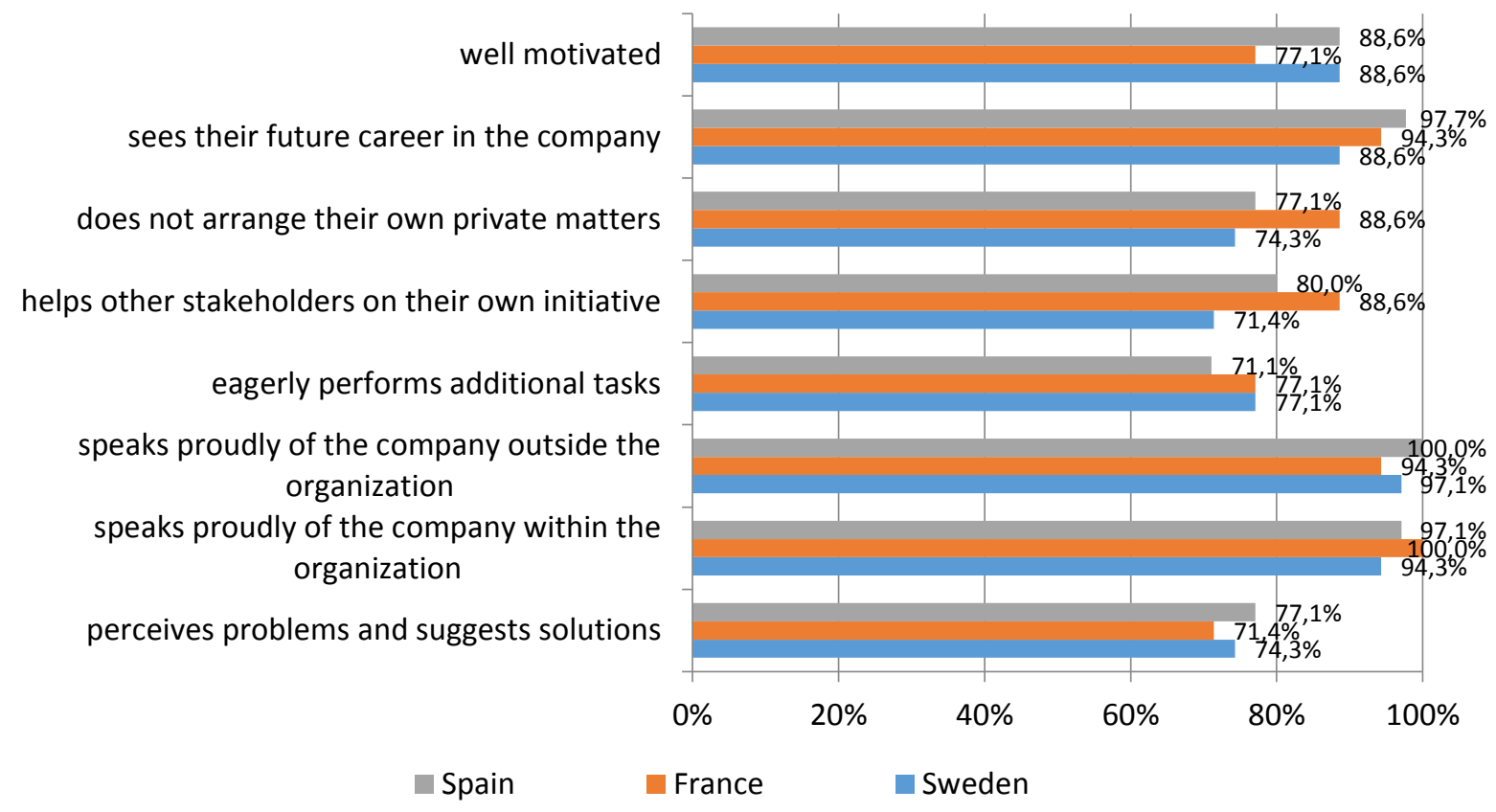

Figure 2. Employee commitment. Source: author's own study.

According to the Swedish directors, an engaged employee is one who sees problems and offers solutions, speaks proudly about the company and all its stakeholders, enthusiastically performs tasks that go beyond their scope of duties, and helps the company's stakeholders on their own initiative. The employee commitment assessment among the surveyed entrepreneurs is conducted twice a year, using the Gallup test (one of the most valued methods for measuring employee commitment, developed by the Gallup Institute). 
According to the Spanish directors, a committed employee speaks positively about the company, performs his duties with enthusiasm and is motivated to apply themselves harder than specified in the scope of duties, and associates their professional future with the company.

The employee commitment assessment the analyzed enterprises is also carried out using the Gallup test, the employees are also subject to assessment by their subordinates, superiors and customers. If the survey results indicate low commitment, a direct, motivational conversation with the supervisor occurs.

On the other hand, the directors from France believe that an engaged employee speaks positively about the company both inside and outside the organization, does not take care of their private matters at work, and helps other stakeholders on their own initiative. The commitment is also measured using the Gallup test. This test is carried out twice a year unless clients or other stakeholders complain about the employees.

At this question, all the respondents primarily emphasized that a committed employee must take care of the good image of their employer. For this purpose, training courses in Employer Branding are organized in France and Spain for all employees to make them realize the importance of positive perception of the brand by stakeholders. The respondents also emphasized that an engaged employee should approach all their tasks with enthusiasm, despite having a negative approach towards them. On the other hand, the directors from Sweden pointed out in their statements that, when signing an employment contract with an employee, they established a joint incentive system, which is consistently being implemented.

The second question was: Does the prestige of the company affect the engagement of newly hired employees? All the directors (100\%) agreed that the employer's image had a positive effect on newly hired employees (Figure 3).

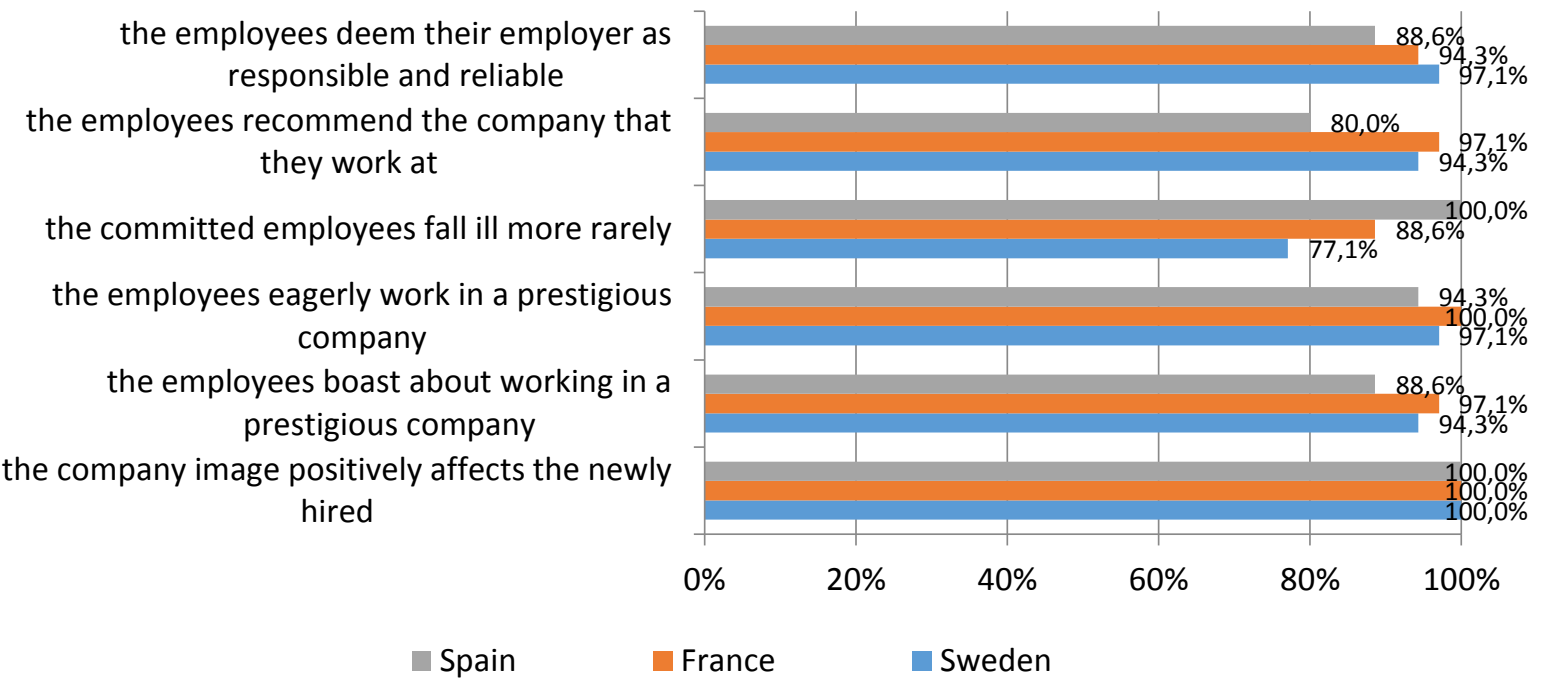

Figure 3. The significance of the company image for a newly hired employee. Source: author's own study. 
The Swedish and French directors emphasized that their employees boasted in social media that they worked in prestigious companies and recommended the company online as a responsible and reliable employer. The Spanish executives have observed in their companies that the level of commitment of a newly hired employee enables a prediction of their level of achievement at work, while absenteeism among employees who are engaged in their work is lower than among those who show a lack of commitment. The next question was: What affects the lack of employee commitment in the work performed? The responses of the Swedish directors differed from those of Spanish and French directors, which in turn were similar (Figure 4).

According to the directors from Sweden, the lack of commitment of their employees results from excessive bureaucracy in the company, the lack of opportunities for professional development, no frequent bonuses, many years of work, routine in performing the same tasks and little or no trust in employees. In the directors' opinion, the age of the employee also affects their commitment to work. It was observed that employees aged over 45 showed greater commitment to work than younger employees.

According to the Spanish directors, the lack of commitment of their employees may result from direct superiors, who do not praise for a job well done, but only criticize for every shortcoming, inappropriate people promoted to managerial positions, lack of trust in employees in the implementation of key projects, lack of quick promotions.

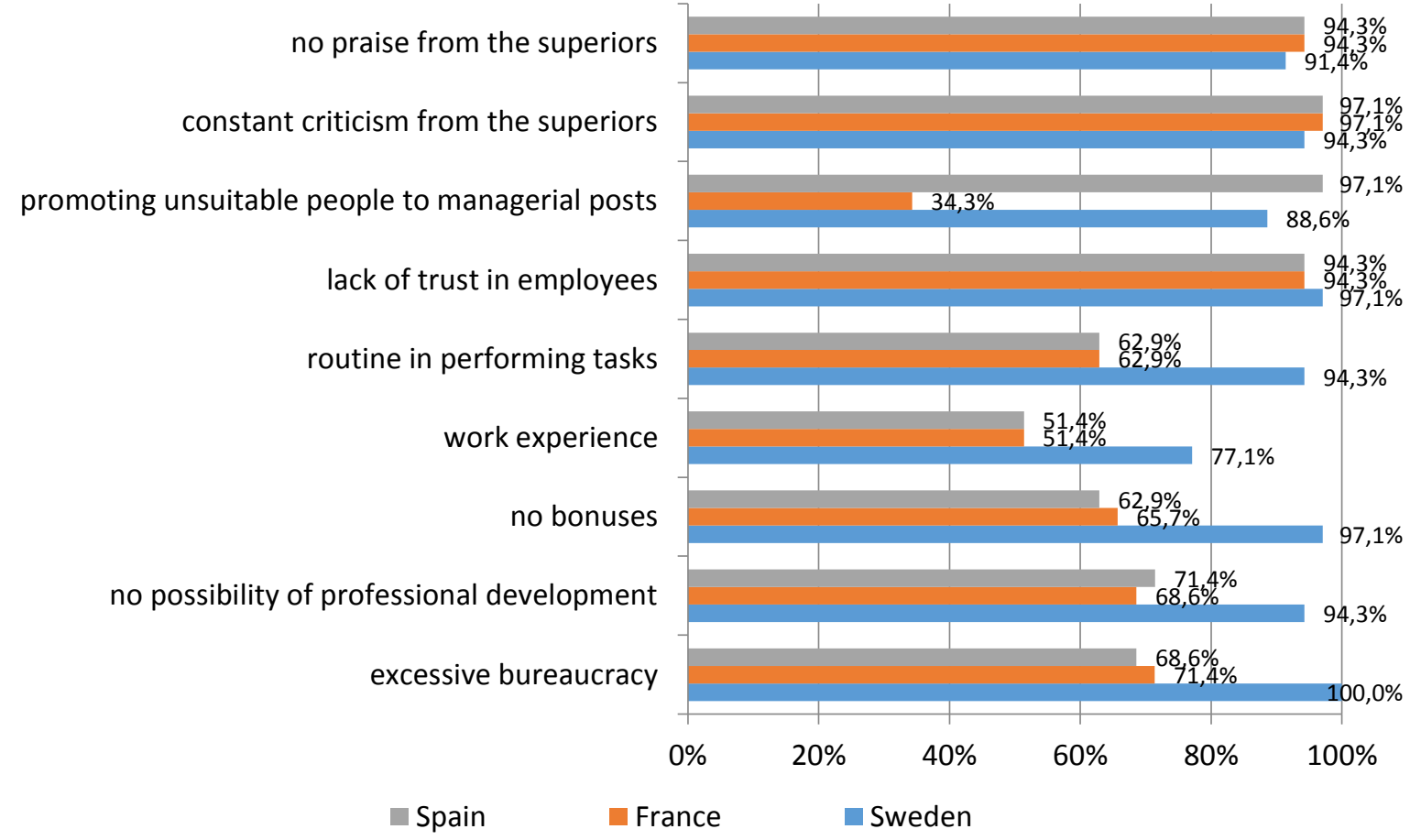

Figure 4. Lack of employee commitment in the work performed. Source: author's own study. 
The responses of French directors largely coincided with those of their Spanish counterparts. In an interview, four directors emphasized that, in their company, neither employees nor their superiors trust each other, and this is due to the fact that the management staff disclosed information about the company's strategy and goals to the competition. The directors also noted that the employees involved in their work did not need supervision of their superiors, and the control by their superiors only demotivated them and so they achieved worse results.

All the surveyed directors were also the owners of their enterprises so it should be assumed that the answers were provided from the perspective of the employer. All the respondents also emphasized that one of the factors that affected the lack of employee involvement was the mutual lack of trust between the employer and the employee.

The question: Does the decrease in employee involvement in work affect the image of the employer? had the same answer from all the respondents (100\%). They unanimously agreed that the involvement of employees in their work has a direct impact on the image of the employer. They also emphasized that there were cases of decreased employee commitment to work, but if they were short, i.e. up to one month, they did not have a negative impact on the image of the employer. Five Swedish executives (14.3\%) described a situation where their employees had defrauded the company's customers and suppliers, which resulted in a decrease in the number of customers and a negative opinion in the press. The respondents also emphasized that their long-term employees have, after several years, developed the so-called passive commitment, i.e. attachment to the organization and remaining therein, but the commitment of the employees in this group is constantly monitored and information is provided to immediate superiors on an ongoing basis.

The question: Are the tools of Corporate Social Responsibility used to shape a positive image of the employer, and if so, which? had all the respondents reply that they did use some CSR tools in their enterprises that have a positive impact on the image of the enterprise.

The Swedish directors most often organize charity actions targeted at the disabled $(82.7 \%)$, and environmental campaigns $(80 \%)$ to make the local community aware of environmental issues. The Spanish and French owners donate a part of their profit to organizations supporting the homeless (71.4\%), give free computer operation and sales technique training courses for the unemployed (68.6\%) and donate part of their profit to environmental organizations $(62.8 \%)$. They also apply transparent management and the ISO 9000 has been implemented in all the companies. The directors from Spain also emphasized in their statements that their employees voluntarily engaged in CSR activities by providing help especially to the sick, the elderly and the poor who needed this help $(88,6 \%)$.

The answers to the following question: What rates of commitment to work did your employees achieve? gave reasons for reflection as the work commitment rates, based on the Gallup test, were very low in all the companies in question: in France 20-30\%, in Sweden $25-35 \%$, in Spain 20-35\%. 
The last question concerned Employer Branding tools used in the Swedish, French and Spanish enterprises (Figure 5). According to the French directors, the most popular EB tools are: job fairs, recruitment videos with employee participation, social media, and 'open doors' in the company. According to the Swedish directors, the most commonly used EB tools are: the professional career tab on the company website, social media, recruitment advertisements, campaigns at universities.

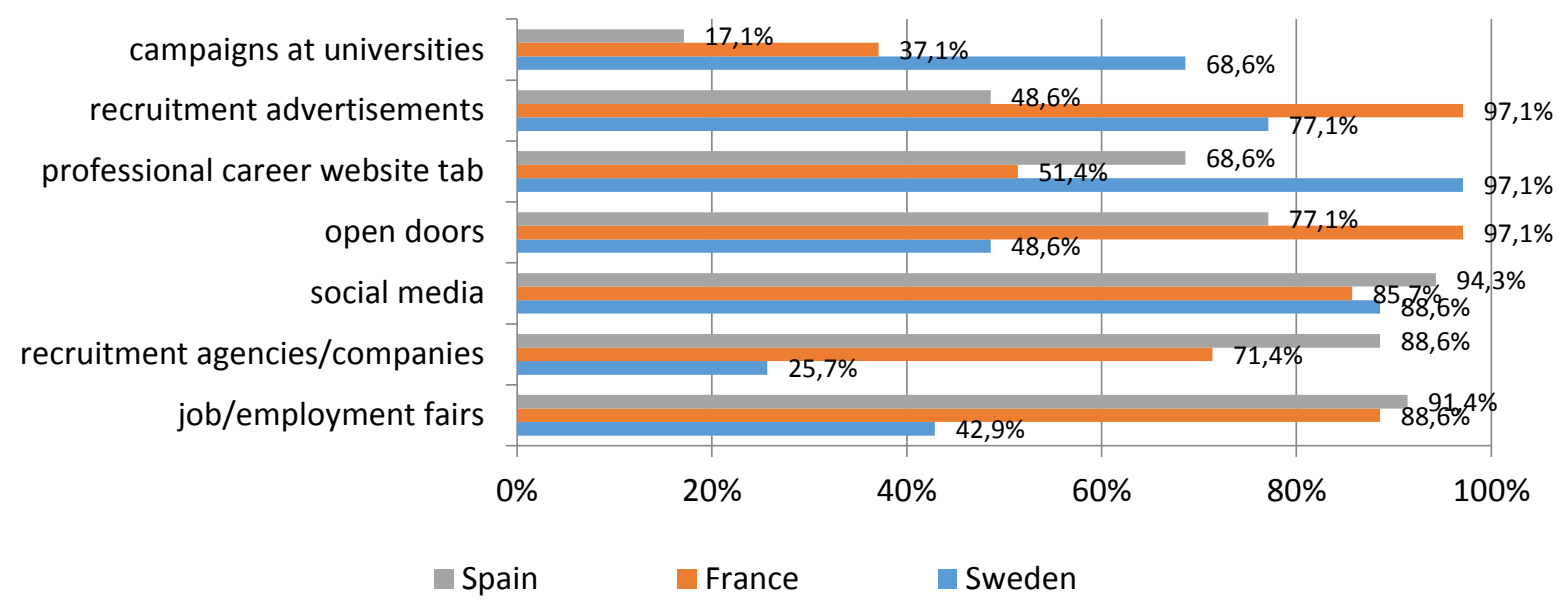

Figure 5. Employer Branding tools used in the surveyed companies. Source: author's own study.

Finally, the Spanish directors most often used social media, job fairs, recruitment videos featuring the company's employees, open doors, career website tabs.

Summing up, it should be stated that the set of key questions contained in the interview questionnaire made it possible to answer the research questions posed. The research done has shown that a decrease in employee commitment to work does not always have a negative impact on the image of the employer, and the applied CSR tools have a positive impact on both the company's image and employee commitment. The mutual lack of trust between owners and managers of the individual enterprises and their employees appears to be a disturbing phenomenon. Low employee engagement rates in the individual countries may well result from that lack of trust.

\section{Instruments for building and stimulating employee commitment and Employer Branding - the European context - results of empirical research}

The role of the immediate superior in building and stimulating employee commitment in work is crucial. According to the Aon Hewitt report, employees under their immediate superiors identify them as representatives of the employer who builds and stimulates their commitment (www.pulshr.pl, 2020). 
The question here was: How is employee commitment built and stimulated in Sweden, Spain, France? The Swedish IT directors pointed to the factors that influence building and stimulating employee commitment. In their opinion, these include:

- motivating setting of goals and accounting for work results $(68.6 \%)$,

- adjusting the scope of duties and task structure to the needs, aspirations and capabilities of employees $(62.7 \%)$,

- involving employees in the decision-making process by delegating decision-making powers and responsibilities (48.6\%),

- communicating to employees the importance of their work for the results of the team, and thus the entire company $(42.9 \%)$,

- providing constructive feedback, both positive and negative (40\%),

- building an appropriate culture (based on cooperation) and a team working atmosphere $(37.1 \%)$,

- providing employees with development opportunities $(82.8 \%)$,

- supporting employees in maintaining a balance between work and private life (51.4\%).

The Spanish directors listed the following as factors building and stimulating employee commitment to work:

- best employee contests $(77.1 \%)$,

- flexible work system (88.6\%),

- daily communication with the superior $(68.6 \%)$,

- providing employees with opportunities for professional development (743\%),

- employee training (54.3\%),

Finally, the responses of the directors from France coincided with those of their Swedish colleagues. Most of the respondents emphasized in their statements that employee commitment is built through appreciation, namely:

- visits by the president at workplaces and talking to employees about their everyday professional problems (42.9\%),

- lunch with the board or senior management for outstanding employees (34.3\%),

- congratulatory letter, diploma, etc. for outstanding employees $(71.4 \%)$,

- contests for employees, which greatly appreciate involvement in extra tasks, effective cooperation with others, activity in project teams, implementing improvements, introducing innovations, etc. (51.4\%),

- coupons for employees for products manufactured/sold by the company (71.43\%),

- celebrating employees' birthdays by handing in greeting cards, flowers or a company gadgets $(42.9 \%)$.

All the respondents emphasized that the factors correctly applied to the expectations of employees influenced the increase in employee commitment in work, which in turn affected the company's economic results and its image. 


\section{Summary and recommendations}

There is a close relationship between the Employer Branding strategy and employee commitment to work. The research results show both similarities and differences in the approach to the discussed issues from the perspective of different countries. Conscious building of the image of the organization as a perfect workplace for current employees and all groups of future stakeholders is the basic principle of every business activity. In order to become an employer of choice, an organization should follow clearly defined principles, trust its employees and meet their needs. These activities will result in employee commitment to work, which will positively translate into the company's image.

It should be noted that organizations should develop individual strategies for the development of human capital based on effective systems of motivating and building employee commitment, systematically examine satisfaction of their employees, implement WLB (work life balance) programs, demonstrate great flexibility in scheduling working time, improve the organization's communication system and also, or above all, to shape and cultivate a culture and atmosphere of trust. The assumed thesis has been confirmed, which means that, despite cultural, economic and political differences, it is possible to find joint organizational activities which positively influence employee commitment and the employer brand of international companies.

\section{References}

1. Ambler, T., and Barrow, S. (1996). The employer brand, The Journal of Brand Management. 4(3), 187.

2. AON (2020). Maleje poziom zaangażowania pracowników na świecie. Retrived from https://www.aon.com/poland/hr/centrum_dla_mediow/Informacje_prasowe/2017/Informa cja_prasowa_2017_gtee.jsp, 28.07.2020.

3. Armstrong, M. (2009). Zarządzanie wynagrodzeniami. Kraków: Wolters Kluwer Polska, 123.

4. Axelrod, E.L., Handfield-Jones, H., and Welsh, T.A. (2001). War for talent. The McKinsey Quarterly, 2.

5. Bednarska-Olejniczak, D. (2013). Wybrane problemy kształtowania wizerunku przedsiębiorstwa jako pracodawcy. In: A. Nedyalkova, and A. Kaczmarek (Eds.), Ekonomiczno-zarządcze problemy w gospodarce. Gorzów Wielkopolski: Wydawnictwo Naukowe PWSZ w Gorzowie Wielkopolskim. Studia i Prace Wydziału Ekonomicznego, 3, 17. 
6. BRIEF (2018). Aon Best Employers 2018 - Najlepsi Pracodawcy wytonieni! Retrived from https://brief.pl/aon-best-employers-2018-najlepsi-pracodawcy-wylonieni/, 28.07.2020.

7. BRIEF (2019). Najlepsze Miejsca Pracy Polska 2019. Laureaci konkursu Great Place to Work®. Retrived from https://brief.pl/najlepsze-miejsca-pracy-polska-2019-laureacikonkursu-great-place-to-work/, 28.07.2020.

8. Chambers, E.G., Foulon, M., Handfield-Jones, H., Hankin, S.M. and Michaels, E.G. III (1998). The war for talent. The McKinsey Quarterly, 3.

9. Dąbrowska, J. (2014a). Przegląd wybranych koncepcji employer brandingowych. In: K. Kubiak (Ed.), Employer Branding $w$ teorii i praktyce. Warszawa: Wyższa Szkoła Promocji, 27.

10. Dąbrowska, J. (2014). Marka pracodawcy czy pracodawca z wyboru - omówienie dwóch różnych podejść do działań employer brandingowych prowadzonych przez organizacje. In: C. Szmidt (Ed.), Nowe nurty w zarzadzaniu i w ekonomii. Warszawa: Poltext, 217.

11. http://www.pulshr.pl, 21.02.2020.

12. IPiSS (2019). Konkurs Lider Zarzadzania Zasobami Ludzkimi, EDYCJA XX. Retrived from https://www.ipiss.com.pl/lider-zarzadzania-zasobami-ludzkimi, 28.07.2020.

13. Juchnowicz, M. (2010). Zarządzanie przez zaangażowanie. Koncepcja. Kontrowersje. Aplikacje. Warszawa: PWE, 34-36.

14. Kaczkowska-Serafińska, M., and Michalska, K. (2015). Employer branding - nowe możliwości dla efektywnych procesów rekrutacji pokolenia Y. ZNUV, 44(6), 98.

15. Kozłowski, M. (2012). Employer branding - budowanie wizerunku pracodawcy krok po kroku. Warszawa: Wydawnictwo Wolters Kluwer Polska, 14.

16. Król, A, Kacprzak, A. (2016). Budowanie zaangażowania pracowników w przedsiębiorstwach sektora ubezpieczeniowego. In: A. Król, M. Kacprzak (Eds.), Instrumenty ksztattowania kapitatu ludzkiego w praktyce przedsiębiorstw. Warszawa: Wydawnictwo Wyższej Szkoły Menedżerskiej, 182.

17. Mayo, A. ( 2001). The Human Value of the Enterprise. London-Boston: Nicholas Brealey Publishing, 123.

18. Warzybok, M. (2020). Aon Best Employers 2018 - najlepsi pracodawcy wytonieni. Retrived from https://brief.pl/aon-best-employers-2018-najlepsi-pracodawcy-wylonieni/, 30.04.2020.

19. Żemigała, M. (2007). Społeczna odpowiedzialność przedsiębiorstwa. Budowanie, zdrowej, efektywnej organizacji. Kraków: Oficyna Wolters Kluwer Business, 100. 